\title{
EFFICACY OF A SYSTEMIC INSECTICIDE IN REDUCING POPULATIONS OF BLACK PINELEAF SCALE (NUCULASPIS CALIFORNICA)
}

\section{by Paul T. Flanagan}

\begin{abstract}
In 2001, 66 ponderosa pines (Pinus ponderosa) infested with black pineleaf scale (Nuculaspis californica) near Leavenworth, Washington, U.S., were selected for an insecticide trial. Twentytwo pines were injected with a systemic insecticide in October 2001; in March 2002, an additional 22 pines were similarly injected. The remaining 22 pines served as a control. Branches were collected in October 2002, and scale density per meter of foliage was compared among the fall treatment, spring treatment, and control trees. Both spring and fall treatments significantly reduced scale densities on 2002 and 2001 foliage. The spring treatment was more effective than the fall treatment.
\end{abstract}

Key Words. Ponderosa pine; black pineleaf scale; systemic insecticide; plant health; IPM; acephate.

Black pineleaf scale (BPLS) (Nuculaspis californica) is distributed over a wide range that includes southern Canada, the United States, and northern Mexico. It is becoming an increasingly important pest in the forest-urban interface. In western North America, local populations cause the decline and death of ponderosa pine (Pinus ponderosa). Weakened trees are predisposed to attack by bark beetles (Ferrell 1986).

Male BPLS fly in search of females, they mate and lay eggs during June, and eggs hatch in July. First instar larvae (crawlers) are wind-dispersed locally and can infest all needles but show a distinct preference for current-year needles. Soon after settling on a needle, crawlers cease movement, begin to feed, and establish a waxy covering. They usually become dormant in October. Scale insects begin to feed again in late winter or early spring when daytime maximum temperatures stay above freezing (Ferrell 1986).

The two most important factors that limit BPLS populations are cold temperatures and parasitism (Edmunds 1973). The rapid onset of freezing temperatures in the fall, before scales become conditioned to cold, can result in significant mortality of these insects. Parasitic wasps are often effective at controlling scale populations (Hanson and Miller 1984). An outbreak of BPLS in Spokane, Washington, U.S., during the 1940s and 1950s was strongly correlated to areas receiving high dust fall. A chronic infestation in and around Leavenworth, Washington, has resulted in significant mortality of ponderosa pines adjacent to apple and pear orchards. In this case, insecticide drift has apparently reduced parasitism of BPLS by Prospaltella near aurantii (Howard) to a negligible level (Edmunds 1973).

The objective of this study was to determine the effectiveness of the systemic insecticide acephate in reducing BPLS densities on ponderosa pine foliage.

\section{MATERIALS AND METHODS}

During the summer of 2001, 66 ponderosa pines were selected for treatment near the Leavenworth Summer Theatre and Leavenworth Ski Hill. These are high-value trees that provide a visual and noise buffer. Tree number 1 was designated for a March 2002 treatment, tree number 2 was designated for a October 2001 treatment, and tree number 3 was designated for a control. This procedure was repeated sequentially through all 66 trees in order to provide a stratified random sample.

Acephate was used for the spring and fall treatments. Acephate is an organophosphate insecticide that kills insects by disrupting normal nervous system functions. Acephate implants have been used successfully to protect ponderosa pine from ponderosa pine needle miner (Coleotechnites ponderosae) in Colorado (Stevens and Leatherman 1982), Douglas-fir (Pseudotsuga menziesii) from western spruce budworm (Choristoneura occidentalis) in Oregon (Koerber and Sandquist 1988), and Chinese hackberry (Celtis sinensis) from citricola scale (Coccus pseudomagnoliarum) in California (Dreistadt and Flint 1995). The commercially available systemic tree implant Acecap releases acephate (orthene) into primary xylem. An individual Acecap contains $0.875 \mathrm{~g}$ of the active ingredient. A tree with a diameter of $33 \mathrm{~cm}$ at breast height would receive $33 * 3.14 / 10.16=10$ implants. Implants are inserted just inside the inner bark, beginning $15 \mathrm{~cm}$ above the ground, with subsequent implants spiraling upward.

In October 2002, a lower needle-bearing branch was cut from each live tree and brought to the U.S. Forest Service Wenatchee lab for analysis. BPLS density was determined with a stereo microscope for 2000, 2001, and 2002 by counting the number of live scales per $1 \mathrm{~m}$ of needles. Needle length was determined by taking the average length of 10 needles. The Kruskal-Wallis nonparametric test (SAS 1997) was used to test two hypotheses: (1) there is no difference in BPLS densities among treatments; (2) there is no difference in needle length among treatments. 


\section{RESULTS AND DISCUSSION}

Tree diameters at breast height ranged from 15.49 to 67.82 $\mathrm{cm}$. The mean was $38.33 \mathrm{~cm}$, and the standard error was $1.47 \mathrm{~cm}$. By October 2002, 15 of the 66 trees were killed by western pine beetles (Dendroctonus brevicomis). The dead trees were distributed rather evenly among the three categories of trees. This level of ponderosa pine mortality is significant but not unusual in the upper Wenatchee Valley. Many of the trees that received acephate had no visible resin response to the implants, an indication of low vigor.

October and March acephate implants significantly reduced the number of crawlers that successfully formed scales on new 2002 foliage $(\mathrm{p}<0.006)$ and on 2001 foliage $(\mathrm{p}<0.027)$ (Table 1). BPLS density on 2000 foliage was unaffected by acephate implants ( $<0.60$ ), probably because older foliage is less desirable to dispersing crawlers.

Because most of the annual needle elongation occurs before scale eggs hatch in July, average needle length did not vary significantly among treatments $(\mathrm{p}<0.74)$. The overall low vigor of these trees and annual variation in precipitation are also important factors affecting needle length.

On October 2002, unusually low temperatures were recorded in Leavenworth (Table 2). This situation might provide temporary relief by increasing the mortality rate of scales that were not cold-hardy. However, western pine beetles are actively killing trees, and parasitism by Prospaltella wasps has apparently not been effective in reducing the scale population to an endemic level. Repeated injections of acephate might slow the demise of these trees.

\section{LITERATURE CITED}

Dreistadt, S.H., and M.L. Flint. 1995. Landscape pest monitoring methods and training managers to use them. J. Arboric. 21(1):1-6.

Edmunds, G.F. 1973. Ecology of black pineleaf scale (Homoptera: Diaspididae). Environ. Entomol. 2(5):765-777.

Ferrell, G. 1986. Black Pineleaf Scale. Forest Pest Leaflet 91. USDA Forest Service. 5 pp.

Hanson, P.E., and J.C. Miller. 1984. Scale insects on ornamental plants: A biological control perspective. J. Arboric. 10(9):259-264.

Koerber, T.W., and R.E. Sandquist. 1988. Timing of trunkimplanted acephate for protection of Douglas-fir from defoliation by the western spruce budworm. West. J. Appl. For. 3(4):126-128.

Statistical Analysis Systems (SAS). 1997. Release 6.12. SAS Institute Inc., Cary, NC.

Stevens, R.E., and D.A. Leatherman. 1982. Implants and Sprays for Control of Ponderosa Pine Needle Miner in Foliage of Individual Trees. Research Note RM-420. USDA Forest Service. 4 pp.

Acknowledgments. The author wishes to thank Roy W. Magelssen for field and laboratory assistance, and Mark A. Gunderson of G\&V Contracting for field assistance. David L. Overhulser and two anonymous reviewers provided helpful comments on the manuscript.

Table 1. Black pineleaf scale density per meter of ponderosa pine needles.

\begin{tabular}{llll}
\hline & \multicolumn{3}{c}{ Needle age } \\
\cline { 2 - 4 } Treatment & 2002 & 2001 & 2000 \\
Control & $97.75($ s.e. 27.28$)$ & $178.25($ s.e. 37.26$)$ & 113.50 (s.e. 19.99) \\
October 2001 & $39.18^{*}($ s.e. 13.03) & $91.47^{*}($ s.e. 16.60) & 119.82 (s.e. 27.50) \\
March 2002 & $22.06^{*}$ (s.e. 6.87) & $70.00^{*}$ (s.e. 15.21) & 87.59 (s.e. 16.45) \\
\hline "Significantly different from control $(2002: \mathrm{p}<0.006 ; 2001: \mathrm{p}<0.027)$.
\end{tabular}

Table 2. Daily minimum temperatures for selected dates in 2002.

\begin{tabular}{ll}
\hline October 25 & $-7^{\circ} \mathrm{C}$ \\
October 26 & $-7^{\circ} \mathrm{C}$ \\
October 30 & $-10^{\circ} \mathrm{C}$ \\
October 31 & $-12^{\circ} \mathrm{C}$ \\
November 2 & $-13^{\circ} \mathrm{C}$ \\
November 3 & $-12^{\circ} \mathrm{C}$ \\
November 4 & $-11^{\circ} \mathrm{C}$ \\
\hline
\end{tabular}

Entomologist

USDA Forest Service

1133 N. Western Avenue

Wenatchee, WA 98801, U.S. 
Résume. En 2001, 66 pins ponderosa infestés par la cochenille noire des aiguilles du pin près de Leavenworth dans l'état de Washington ont été sélectionnés pour un essai d'insecticide. Vingt-deux pins ont été injectés avec un insecticide systémique en octobre 2001; en mars 2002, un nombre additionnel de 22 pins ont été traités de manière similaire. Les 22 pins restants ont servis quant à eux de groupe-témoin. Des branches ont été récoltées en octobre 2002 et la densité par mètre linéaire de feuillage en cochenilles a été comparée entre les différents groupes d'arbres traités. À la fois les traitements en automne et au printemps ont permis de réduire la densité en cochenilles sur le feuillage de 2002 et de 2001. Le traitement au printemps a été plus efficace que celui en automne.

Zusammenfassung. 2001 wurden in Leavenworth, Washington, 66 befallene Ponderosa-Kiefern für einen Insektizidversuch ausgewählt. 22 Kiefern wurden im Oktober 2001 mit einem systemischen Insektizid injiziert und im März 200222 weitere Kiefern. Die verbleibenden Kiefern stellten die Kontrollgruppe dar. Im Oktober 2002 wurden Äste gesammelt und die Dichte des Insektenbefalls pro Meter Laub zwischen den beiden Behandlungen und der Kontrollgruppe verglichen. Beide Behandlungen (Herbst und Frühling) reduzierten deutlich den Befall in 2001 und 2002. Die Frühlingsbehandlung war effektiver als die Herbstbehandlung.

Resumen. En 2001, 66 pinos ponderosa cerca de Leavenworth, Washington, infestados con la escama negra de la hoja fueron seleccionados para un ensayo con insecticida. Veintidós pinos fueron inyectados con un insecticida sistémico en Octubre de 2001; en Marzo de 2002, y 22 pinos adicionales fueron similarmente inyectados. Los restantes 22 pinos sirvieron como control. Las ramas fueron colectadas en Octubre de 2003, y la densidad de las escamas por metro de follaje fue comparada entre los tratamientos de otoño, primavera y árboles de control. Ambos tratamientos de primavera y otoño redujeron significativamente las densidades de la escama en el follaje de 2001 y 2002. El tratamiento de primavera fue más efectivo que el de otoño. 